\title{
Diffuse Glioma
}

National Cancer Institute

\section{Source}

National Cancer Institute. Diffuse Glioma. NCI Thesaurus. Code C129325.

A glioma that has diffusely infiltrated the surrounding central nervous system tissues. 